12.

\title{
The Transformation of Final Causation: Telesio's Theories of Self-Preservation and Motion
}

\section{Rodolfo Garau}

In an attempt to overcome the widespread narratives of Telesio as a precursor of Newton (Cassirer) or as a prisoner of an unscientific form of hylozoism (Gentile), ${ }^{1}$ current scholarship has increasingly emphasized the anti-Aristotelian traits of Telesio's philosophy as his most historically relevant contribution to the development of early modern natural philosophy. In a paper tellingly entitled The First of the Moderns or the Last of the Ancients?, Guido Giglioni argued that the notion of sentience, far from representing an outmoded vestige of a naive animism, provided the basis for a radical shift from the Aristotelian notion of movement, and thus must be seen as the most original trait of Telesio's natural philosophy. Giglioni writes,

....the Aristotelian notion of nature suffered from an ineliminable residue of Platonism, in that all natural beings, in their irresistible tendency to be actualized by the form, appeared to be drawn to a principle that in the end transcended nature itself, regardless of whether that principle was the unmoveable mover, the pure actuality of the ultimate form or the active intellect. Put in a nutshell, the actions of nature were supposed to terminate in something other than nature itself. ${ }^{2}$

Detaching himself from the fundamental kernel of Aristotelian natural philosophy, Telesio saw in the Aristotelian notion of nature an insufferable deviation from his project of understanding nature iuxta propria principia. While he did not reject the project of understanding nature within a teleological framework or declaring teleology as present but unintelligible (as many seventeenth-century inquirers would do), Telesio rejected the idea that the telos was somehow situated outside of nature. As Giglioni observes,

\footnotetext{
${ }^{1}$ See Ernst Cassirer, Das Erkenntnisproblem in der Philosophie und Wissenschaft der neueren Zeit (Berlin: Verlag Bruno Cassirer, 1922); Giovanni Gentile, "Bernardino Telesio," in Opere complete di Giovanni Gentile: I problemi della Scolastica e il pensiero Italiano (Florence: Sansoni, 1963), 133-206.

${ }^{2}$ Guido Giglioni, "The First of the Moderns or the Last of the Ancients? Bernardino Telesio on Nature and Sentience," Bruniana \& Campanelliana 1 (2010): 85.
} 
[Telesio first] dismissed the notion of nature as an unconscious source of activity by emphasizing instead its fully sentient character; second, he demonstrated that the view of unintentional finalism was a pure abstraction of the intellect, for nature could not be regarded as occupying an autonomous sphere of activity without adding the decisive qualification that it has to be aware of its ends and purposes. ${ }^{3}$

The reaction of Telesio's contemporaries to the publication of De rerum natura seems to confirm that what struck its readers was its proposal of a system of natural philosophy that represented a coherent and all-encompassing alternative to Aristotelianism. ${ }^{4}$ Its novelty was not necessarily seen in the alternative physical theses that Telesio was propounding but rather in its ambitious attempt to replace Aristotelianism from its very fundaments. In 1572, the Platonic philosopher Francesco Patrizi was asked to draft some of his major objections to Telesio's theories. On that occasion, he was certainly not very lenient with Telesio's work. Patrizi accused Telesio of reviving the vision of nature of the pre-Socratic philosopher Parmenides. Second, Patrizi observed that, beyond his well-known claim that all true knowledge either derives from sensation or is developed by means of analogy with sensory experience, Telesio largely based his theories on abstract reasoning. The scarce reference to direct observation is also exemplified, according to Patrizi, by Telesio's glaringly counterfactual claims such as that heat cannot derive from motion but, vice versa, that heat always precedes motion as a substance precedes its operation. On the contrary, the most coherent aspect of De rerum natura seemed to Patrizi to be the second book, devoted to the confutation of concurrent Aristotelian theories - therefore the pars destruens more than the pars costruens of Telesio's system. Patrizi described this part of De rerum natura as "greatly worthy of admiration". 5 Similarly, a few years later, the Italian philosopher Tommaso Campanella would seek in Telesio's De rerum natura a source to elaborate an alternative to Scholasticism. ${ }^{6}$

Framing Telesio's thinking in the context of the (pre-?)modern polemics against Aristotelianism surely provides a more historically sound understanding of his works. Developing the image of Telesio as "first of the moderns" in Bacon's words, scholars have sometimes popularized him as a forerunner of Newton, an advocate of sensory knowledge, a denier of the authority of Aristotle, a critic of the esotericism of contemporary magical and

\footnotetext{
${ }^{3}$ Giglioni, "The First of the Moderns or the Last of the Ancients?"

${ }^{4}$ On this, see also Pietro Omodeo's Introduction to this volume. Bondì provides a very good discussion of Telesio's influence in Roberto Bondi, Introduzione a Telesio (Rome: Laterza, 1997).

${ }^{5}$ See Francesco Fiorentino, Bernardino Telesio. Ossia Studi Su L'idea Della Natura Nel Risorgimento Italiano, vol. 2 (Florence: Le Monnier, 1874), 375-98.

${ }^{6}$ See Nicola Badaloni, Tommaso Campanella (Milan: Feltrinelli, 1965).
} 
hermetic knowledge (see for instance Cassirer). Other times, instead, they have deemed his reference to animism and universal sensibility a vestige of magical and pre-scientific thought (as for instance Gentile). ${ }^{7}$ Against these narratives, projecting Telesio's work against the background of Aristotelianism surely represents a more insightful way to represent his work. At the same time, however, this makes the evaluation of Telesio's influence on early modern thought (and in particular on the development of seventeenth-century proto-inertial natural philosophy) more problematic. Certainly scholars have shown that his work influenced major seventeenth-century intellectuals such as Bacon, Descartes, Gassendi, and Hobbes. ${ }^{8}$ At the same time, these authors (with the notable exception of Bacon) rarely referred directly to Telesio in their works, and almost never as a source of their theories. Therefore, the problem of how to treat the relationship between Telesio and seventeenth-century natural philosophy seems to be an almost insurmountable methodological riddle.

This paper focuses on a notion closely connected to that of sentience, indicated by Giglioni as the most original trait of Telesio's philosophy - that of self-preservation. In De rerum natura iuxta propria principia, Telesio argues for the existence of two antithetical active principles, heat and cold, in turn corresponding to the Sun and heaven and to the Earth respectively, and yielding motion and change and rest and immutability. Heat and cold, rather than actively producing the matter on which they act, are the principles of its change, while the "mass or body" (moles vero corpus) on which the two active natures act remains, although its nature and form changes (I, 5, 17). ${ }^{9}$ Telesio attributed a crucial role to self-preservation, arguing that both principles are essentially antithetical and tend to counteract each other, seeking their own preservation.

The aim of this paper is not to offer a genealogical reconstruction of Telesio's notion of selfpreservation (as Martin Muslow has already remarkably done) ${ }^{10}$ but rather to analyse this

\footnotetext{
${ }^{7}$ Cassirer, Das Erkenntnisproblem; Gentile, Opere complete, 133-206.

${ }^{8}$ See for instance Bondì, Introduzione a Telesio; Karl Schuhmann, "Hobbes and Renaissance Philosophy," in Hobbes Oggi, ed. Andrea Napoli (Milan: Angeli, 1990); Martin Mulsow, Frühneuzeitliche Selbsterhaltung: Telesio und die Naturphilosophie der Renaissance (Tübingen: Niemeyer, 1998).

${ }^{9}$ Latin quotations are taken from Bernardino Telesio, La natura secondo $i$ suoi principi, trans. Roberto Bondì (Milan: Bompiani, 2009).

10 In a book devoted to Telesio's notion of self-preservation, Martin Muslow (Frühneuzeitliche Selbsterhaltung: Telesio und die Naturphilosophie der Renaissance) cautioned against viewing Telesio through the later narratives of the "Parmenidean sect" and of the revival of Stoic thought, which would put Telesio in direct connection with Vives and Spinoza. In contrast, he demonstrated a profound connection between Telesio's notion of self-preservation and the medical, astronomical and optical discussions of the time, the diachronic transformations of Aristotelianism and Galenism, as well as the Avicennian and Averroistic influence in sixteenth-century Padua, where Telesio was educated. See Muslow, Frühneuzeitliche Selbsterhaltung, 397: "Die Phasen, die sich als Schwellenzeiten in der
} 
concept and its use within Telesio's natural philosophy, with special regard to Telesio's doctrine of motion. While here I intend to provide a working hypothesis rather than a solid Wirkungsgeschichte (as, as I have suggested before, a study of Telesio's influence on early modern culture is made difficult by a patent scarcity of sources), I suggest that this doctrine likely had a lasting influence on seventeenth-century developments of natural philosophy. I argue that Telesio's notion of self-preservation represents not only another element of critique of Aristotelianism but also a crucial turn in the way Scholastic physics had understood activity in nature. Second, I show that Telesio's notion of self-preservation was likely motivated by the need of providing an alternative to the Aristotelian theory of motion, and in particular was rooted in some crucial inconsistencies in Aristotle's theory of falling objects. In the conclusion of my paper, I hint on some possible bearing of Telesio's doctrine of self-preservation on early modern proto-inertial natural philosophy, in particular in authors such as Descartes and Spinoza. While it is not possible to establish a direct influence of Telesio's natural philosophy on these authors, and despite I reject the narratives of Telesio as a "forerunner" or "anticipator" of modern mechanism, I argue that Telesio's critique of the Aristotelian doctrine of motion and activity, and its explanation in terms of self-preserving tendencies, likely contributed to the creation of the intellectual atmosphere from which early modern mechanism stemmed.

This paper is divided into four sections. I first offer a short reconstruction of the theme of selfpreservation in Western philosophy, focusing in particular on its reception within Scholasticism. Second, I reconstruct Telesio's notion of self-preservation. Third, through a comparison with the Scholastic (and even pre-Scholastic) notion of self-preservation, I show that Telesio's detachment from the Scholastic tradition consisted of three traits: (1) the claim that this tendency to self-preservation is teleologically oriented but not intrinsically definite in time (i.e. does not have a terminus ad quem); (2) while the Thomists grounded the drive to self-preservation within a structured theological framework (in which the instinct to self-preservation stems from the love of God for his creation), Telesio's project of a study of nature "within its own principles" excludes such a theological structure; (3) closely connected to the previous two points, this

Entwicklung des Begriffs der conservado sui herausgestellt haben, mußten erst gegen die Blockade von Mythen der Rezeptionsgeschichte freigelegt werden. Die grands récits, die durch vorschnelle Vereindeutigungen der Positioniserung Telesios die faktischen Verhältnisse verdunkelt haben, sind im 17. und 18. Jahrhundert die Fabel von der Wiederbelebung der parmenideischen $>$ Sekte $<$ durch Telesio und im 19. Jahrhundert die Vorstellung einer frühneuzeitlichen natürlichen Geisteswissenschaft $<$ aufgrund einer durchgängigen Stoa-Rezeption von Vives bis Spinoza gewesen." 
solution brings about a decisive shift from a teleology conceived as the passage between different states and having goals extrinsic to the subject to one that I will define as "autotelic", in which the subject itself (its persistence in existence and increase in power) becomes the goal of activity. Fourth, I show how the notion of self-preservation helps to provide (and was likely motivated by the search for) an alternative explanation to Aristotle's theory of motion, which was rooted in the dualism between natural and violent motion. In Telesio's mind, selfpreservation replaces the idea that the tendency to motion is brought about by the form of things. The conclusion is admittedly the most hypothetical part of my paper. Indeed, the autotelic drive to self-preservation characterizes many (proto)inertial natural philosophies of the seventeenth century, such as that of Descartes and Spinoza. While it is uncertain to what extent Telesio's philosophy influenced these authors, I argue that Telesio's notion of self-preservation helped to create the intellectual atmosphere that led to further development of seventeenth-century mechanism.

\section{The concept of self-preservation: an ancient legacy}

The idea that living entities, and all things in general, tend to act in a self-preserving fashion is likely one of the most widespread ideas in the history of Western thought. One of the main points of contention between the Stoics and Epicureans consisted precisely in establishing the nature of what they called hormé, i.e. the first (or fundamental) action of living entities or their natural inclination to action. Stoics claimed that hormé was addressed to self-preservation (which in turn they believed was accomplished through the unfolding and realization of the animal essence, a process they termed oikeiosis) and resulted from the providential action of an immanent God, while the Epicureans (who denied divine providence by stating that the universe originated by chance) believed that it was addressed to the search for pleasure and the avoidance of pain. This debate was recorded by many ancient 'historians of philosophy', as for instance Diogenes Laërtius:

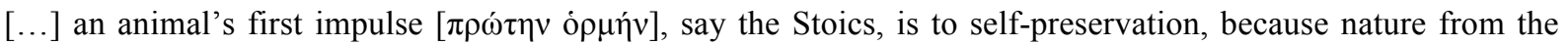
outset endears it to itself, as Chrysippus affirms in the first book of his work On Ends: his words are, 'The dearest thing to every animal is its own constitution and its consciousness thereof'; [...] We are forced to conclude then that nature in constituting the animal made it near and dear to itself; for so it comes to repel all that is injurious and give free access to all that is serviceable or akin to it. As for the assertion made by some people 
that pleasure is the object to which the first impulse of animals is directed, it is shown by the Stoics to be false. For pleasure, if it is really felt, they declare to be a by-product, which never comes until nature by itself has sought and found the means suitable to the animal's existence or constitution ${ }^{11}[\ldots]$.

Animals, as much as men, appear to be endowed with a natural instinct to know what is harmful and what is helpful to them. Their actions in the world, despite not being determined by ratiocination, seem to be motivated by a fundamental instinct to survive and by an innate knowledge of what could be useful to this aim. The Stoics seem to have believed that such instinct revealed the providential action of nature. For instance, Cicero noted that "Nature has provided with bounteous plenty for each species of animal that food which is suited to it .... But nature has also bestowed upon the beasts both sensation and desire, the one to arouse in them the impulse to appropriate their natural food [conatum haberent ad naturales pastus capessendos], the other to enable them to distinguish things harmful from things wholesome"(II, XLVIII). ${ }^{12}$

The great historian of ideas Wolfson ${ }^{13}$ claimed that the Stoic idea of hormé was taken up by philosophers as diverse as Augustine, ${ }^{14}$ Thomas Aquinas and Dante Alighieri in the Middle Ages. It is hard to establish whether this was a direct Stoic influence or a parallel development. Surely, the Christian conception of God as a loving and caring demiurge reinforced the connection between self-preservation and divine providence. Here, the Augustinian notion of "natural love" - the love all creatures have for the means that are useful to their preservation, caused by and reflecting God's providential love for his creation - assumes crucial importance. Aquinas claimed that the greatest example of this was that each and every thing had a natural

\footnotetext{
${ }^{11}$ Diogenes Laërtius, Life of Eminent Philosophers, trans. Robert Drew Hicks (London-New York: Loeb Classical Library, 1925), 193.

12 Marcus Tullius Cicero, De Natura Deorum. Academica, trans. Harry Rackham (Cambridge, MA: Harvard University Press, 1967), 239. See also Ibid., 178: “... as the other natural substances are generated, reared and sustained each by its own seeds, so the world-nature experiences all those motions of the will, those impulses of conation and desire ("conatus et adpetitiones"), that the Greeks call hormae, and follows these up with the appropriate action in the same way as do we ourselves, who experience emotions and sensations" (II, 58).

${ }^{13}$ See Harry A. Wolfson, The Philosophy of Spinoza (Cambridge, MA: Harvard University Press, 1934).

14 Augustine, The City of God Against Pagans, trans. George McCracken (Cambridge, MA: Harvard University Press, 1968), 537: "What of animals in general, even irrational animals that have no power to reflect on these things? Do they not, from huge serpents down to tiny little worms, what that they want to go on being and, in order to do so, seek to escape death by every movement at their command? What of trees and shrubs of every kind that have no sensation to enable them to avoid destruction by perceptible movement, yet do they not ensure the growth of their topmost germinal shoots into the air by fixing another growth, of root, into the ground so as to draw nourishment from it and so, in their own fashion, preserve their existence?" (XI, 27).

${ }^{15}$ Dante Alighieri, Monarchy, trans. Donald Nicholl (London: Weidenfeld \& Nicolson, 1954), 20: “... everything that is desires its own being ..." (I, 13).
} 
appetite for its own preservation. ${ }^{16}$ In Summa Theologiae, using the Aristotelian idea of "practical good", he described this natural appetite for self-preservation as the love "with which each and every particular thing loves its own good because of the common good of the whole universe, that is God" (I-II, q. 109 a. 3 co.). ${ }^{17}$ In another passage of De veritate, he quotes Boethius to link self-preservation to divine providence: "Everything that already exists loves its particular being naturally, and preserves it with all its strength; from which Boethius says in the third book of De consolatione: divine providence gave to the things it created such greatest cause of persisting, so that, insofar as they can, they naturally desire to persist" (Q. 21 a. 2 co.). ${ }^{18}$ However, while animals cannot avoid this natural drive toward their practical good, humans represent a more peculiar case. While each and every human being possesses a "natural appetite" by virtue of which (s)he wants to "exist and live", "the disposition of human actions to the end is not according to nature, as it happens with the irrational creatures, that act towards the end according to natural appetite only, but man acts towards an end through reason and will. So there is no natural law for human beings" (Summa Theologiae I-II, q. 91 a. 2 arg. 2). ${ }^{20}$ While eventually also the rational and voluntary determination of actions depends on the love for good itself (God), Aquinas here is describing man as an "empire within an empire" (to use Spinoza's famous expression), whose actions do not strictly comply to any law.

\section{Telesio's notion of self-preservation}

The passage from a teleology understood as tending to something beyond nature to one in which that something is reabsorbed within the domain of nature (which Giglioni describes in the

\footnotetext{
${ }^{16}$ Thomas Aquinas, On the Power of God, trans. English Dominican Fathers (London: Burns Oates \& Washbourne, 1933), 79: "Everything has a natural appetence [appetitu naturali] for the preservation of its existence" (Q. 5, Art 1, 13).

17 Aquinas, Summa Theologiae, electronic edition, http://www.corpusthomisticum.org/: "Manifestum est autem quod bonum partis est propter bonum totius. Unde etiam naturali appetitu vel amore unaquaeque res particularis amat bonum suum proprium propter bonum commune totius universi, quod est Deus."

18 Aquinas, De veritate, electronic edition, http://www.corpusthomisticum.org/: “Omnia autem quae iam esse habent, illud esse suum naturaliter amant, et ipsum tota virtute conservant; unde Boetius dicit in III de consolatione: dedit divina providentia creatis a se rebus hanc vel maximam manendi causam, ut quoad possunt, naturaliter manere desiderent. [...]."

19 Aquinas, Summa Theologiae, electronic edition, http://www.corpusthomisticum.org/: "Uno quidem modo, appetitu naturali, sicut omnes homines volunt esse et vivere" (II-II, q. 30 a. 1 co.).

${ }^{20}$ Aquinas, Summa Theologiae: "... ordinatio humanorum actuum ad finem non est per naturam, sicut accidit in creaturis irrationabilibus, quae solo appetitu naturali agunt propter finem, sed agit homo propter finem per rationem et voluntatem. Ergo non est aliqua lex homini naturalis."
} 
passage quoted in the introduction above) can be found, perhaps even more glaringly, in Telesio's notion of self-preservation. In Telesio's system, matter, per se neutral and amorphous, is dominated, and continuously transformed by, two principles: heat (having as its source the Sun and heaven and representing a principle of indefinite motion) and cold (having its place on the Earth and naturally deprived of motion). Heat and cold, rather than actively producing the matter on which they act, are the principles of its change, while the "mass or body" (moles vero corpus), on which the two active natures act, remains, although its nature and form change $(\mathrm{I}, 5){ }^{21}$ The Earth, and in particular its surface, is the battlefield of these two opposite principles, from which all things, both organic and inorganic, originate.

In this system, the notion of self-preservation assumes a particular value. Placing two mutually antagonistic active principles, heat and cold, at the core of his view of nature and an informed and passive substance, matter, as the battleground between these two principles, Telesio gives the tendency to self-preservation a fundamental role in his natural philosophy. The two principles cannot fade away in time, leaving behind them an uninformed matter. In this context, the tendency to self-preservation becomes the key element to explain the mutual action of the two principles. In other words, self-preservation represents their essential, antagonistic way of acting upon each other to inform matter. As Telesio writes,

Since it never forgets its disposition, each active nature [natura agens] never desists from acting [nunquam agere cessat] but fights and repels even similar natures to expand in their places, desiring to the greatest extent to be equal to itself and to preserve itself [talis esse servarique], and to expand to a greater extent [...] $(\mathrm{I}, 13)^{22}$

In this framework, the justification for the presence of this sheer instinct to self-preservation is provided by the combination of several qualities. If natures are endowed with this drive to selfpreservation, they must be endowed not only with an appetite for their own preservation (conservationis appetitum) and with hate of their own destruction (propriae destructionis odium) but also with a form of sensation, which Telesio describes as a "force" or "faculty" (vim) to recognize what is contrary and dissimilar to them and what can preserve or corrupt them. As he writes,

\footnotetext{
${ }^{21}$ Telesio, La natura secondo i suoi principi, 16.

22 “...qualiscunque enim existit natura agens quaevis nunquam proprii ingenii oblita nunquam agere cessat, sed vel similes cognatasque oppugnat deturbatque, ut in earum se ipsam sedibus amplificet qualiscunque est talis esse servarique et diffundi amplius atque in subiectis produci omnibus summe appetens summeque contendens. Quod igitur dictum est agentia rerum calor esse frigus videntur." (I, 13, 38).
} 
...the faculty of feeling [sentiendi facultatem] was given to both active natures, and only in this the Earth and the Sun resemble each other [...]. But if natures were to preserve themselves [si servandae sint naturae], not only was it necessary that they had a great desire to preserve themselves [conservationis appetitum] and a great hate of their own destruction [propriae destructionis odium] but also the faculty to recognize what is alike and similar and what is contrary and dissimilar [cognata similiaque et contraria dissimiliaque dignoscendi vim]. Indeed, they would not desire to preserve themselves [conservari appetant] nor they would fight corruption [corrumpi aversentur] if they could not recognize which things preserve and which corrupt them, and if they were not bound to the inclination to repel the former and to pursue the latter (I, 34). ${ }^{23}$

Since matter is inert and not endowed per se with any quality, all sensation (even that of animals or human beings) must derive from the natures that inform matter. As Telesio claims, as heat and cold were given the feeling of their own preservation and destruction [propriae conservationis et propriae destructionis sensus], it is necessary that all beings are also endowed with them, i.e. that the active natures present in each body feel; indeed, what beings are, act and undergo is due to the natures that constitute them, because matter per se lacks any knowledge of itself [conservationis et proprii boni sensus] (I, 34).

Rooted in the very essences of the two natures, sensation embraces the whole of nature, from inanimate to animate bodies. What is more, the sensation of superior beings not only is not a characteristic they possess exclusively, it is also due to the action of the two principles. Nerves and sensory organs are only paths that channel the action of the principles rather than representing the faculty of sensation per se. On this basis, Telesio's account of self-preservation will embrace animate beings as well as inanimate ones. ${ }^{24}$

\section{Telesian self-preservation vs Scholastic self-preservation}

The use of an "anthropomorphized" lexicon in the natural discourse was surely not exclusive to the Telesian account of natural phenomena. Rather, the idea that natural things possessed "appetites", "impulses" or "tendencies" can be commonly found in Scholastic treatises on natural

\footnotetext{
23 "Sentiendi facultatem naturae agenti utrique traditam esse, et in ea sola Caelo Terram coonvenire [...]. Si servandae sunt naturae, non summum modo illis conservationis appetitum summumque propriae destructionis odium indi oportuit, sed cognata insuper similiaque et contraria dissimiliaque dignoscendi vim; frustra enim conservari appetant et corrumpi aversetur, nisi a quibus serventur et a quibus obleadantur disgnoscant, et fugiendi haec et sectandi illa studio teneantur" (Telesio, La natura secondo i suoi principi, 104).

${ }^{24}$ See for instance I, 35. Here, Telesio claims that all beings, also those that do not have sensory organs, possess sensibility.
} 
philosophy. In Summa contra Gentiles, Aquinas describes in the following way the tendency of the stone to descend:

...there is in every thing an appetite for good [appetitus boni]: for good is what every thing desires [appetuntur], as the philosophers teach. In this way, the appetite in things that lack thought is said to be a natural appetite, as for instance it is said that the stone desires [appetit] to be below. In things which have sensitive thought, it is said to be an animal appetite, which is divided into concupiscible and irascible. In things which have intelligence, it is said to be an intellectual or rational appetite, which is will (Summa contra Gentiles, Lib. II, cap. 47 n. 2.). ${ }^{25}$

Still in the seventeenth century, Goclenius, in his Lexicon Philosophicum, distinguished three proper usages ["naturalis appetitus", "animalis appetitus" and "appetitus" of the "naturae intelligentis \& voluntariae"]. Goclenius himself underlined the "ambiguous nature of the term", showing that an "appetite" is said to be "of fire to occupy the superior places, of iron to conjoin with the magnet, of plants to absorb the lymph, of horses to Venus [to pleasure], of men to beatitude". "Naturalis appetitus", an acceptation that Goclenius describes however as somewhat inappropriate ["...qui dicitur quodammodo improprie appetitus", "that is called somewhat inappropriately appetite"], applies both to "plants which attract toward themselves and desire aliments without sensibility [“... in stirpe, quae attrahit \& appetit alimentum absque sensu [...]" and to "inanimate things, such as the magnet ["In inanimis, ut magnete"]."26

The real novelty of the Telesian account of self-preservation consists in its lack of spatial and chronological determination, i.e. its lack of telos or terminus ad quem. In Scholastic philosophy, the preservative action of things was always identified with the achievement of the end that qualified the essence of the thing in question. As Aquinas epitomizes in his Summa theologiae, “...goodness is what all things desire [appetunt], that is, what they have as an end; it is clear that goodness is what is brought about in reason of the end."27

In contrast, in Telesio's picture of nature the search for "goodness", i.e. the search for the preservation and increase of the principles' essence, is an activity that is not restrained or confined in time and does not have a final conclusion - either temporal or spatial. While, say, the

\footnotetext{
${ }^{25}$ Enrique Alarcón, “Corpus Thomisticum”, www.corpusthomisticum.org, 2000.

26 "Distinctio ambigae verbi naturae. Appetitus ó $\mu$ ovv́ $\mu \omega$ dicitur: In igne ad occupanda loca superiora:in ferro ad sui conjunctionem cum magnete: in planta ad humore sugendum: in equo ad Venerem: in homine ad beatitudinem", Rudolph Goclenius, Lexicon Philosophicum (Frankfurt: Becker, 1613), 114. Similarly, Francesco Bonamici, in his De Motu, used the term 'appetitus' and provided a general definition of it as the "inclination [inclinatio] which is necessary from the nature of every thing to agree to the good that convenes to itself according to nature." See Bonamici, De Motu (Florence: Apud Sermartellium, 1591), 28.

27 “...bonum sit quod omnia appetunt, hoc autem habet rationem finis; manifestum est quod bonum rationem finis importat" (Aquinas, Summa Theologiae I, q. 5 a. 4 co.).
} 
appetitum boni of the stone to reach its natural place is fulfilled (at least partially) once it touches ground, the appetite for preservation of Telesian principles characterizes their eternal, unrestrained activity. This marks a passage from a hetero-teleological picture of nature to an autotelic one, i.e. one in which the maintenance and increase of a thing's nature becomes the only way activity can be understood. As a consequence, the activity of a thing that does not suffer from the action of its contrary is potentially infinite:

...in order for a thing to be for eternity and in infinite time, and therefore operate according to its own nature in infinite time, there is no need to be incorporeal or infinite itself, or that it needs to be supported by such a thing. On the contrary [it is only necessary that], as little as the thing can be, it does not suffer from its contrary and it is not changed (DN1, II, 55).

Another fundamental novelty of Telesio's notion of self-preservation is its disconnection from the theological framework that, as we have seen, traditionally associated it to the notion of divine providence. To provide a further example of this connection between divine providence and selfpreservation, we can quote once again Aquinas. In De potentia, answering the first article of the Quaestio 5, Aquinas asks whether "things are preserved in being by God, or, any action of God excluded, they persist in being by themselves. ${ }^{28}$ A possible argument in favour of the latter option, Aquinas states, is that "...the natural appetite cannot be vain and false. But each natural thing naturally desires the preservation of its own being. Therefore a thing can be preserved through itself, otherwise natural appetite is vain." ${ }^{29}$ However (and this is Aquinas's position), things can well possess an appetite for their own preservation but have no power to preserve themselves in being: they are preserved in being by their cause - namely, by God. As he writes, “...it is admissible that every thing naturally desires its own preservation, though not that it is preserved by itself but by its cause." 30

Through his notion of self-preservation and universal sensibility, Telesio completely overturns this perspective. As we have seen, in order to justify the fact that things act selfpreservingly, "not only was it necessary that they had a great desire to preserve themselves

\footnotetext{
${ }^{28}$ De potentia, Q.5 Art.1: “...utrum res conserventur in esse a Deo, an etiam circumscripta omni Dei actione, per se in esse remaneant."

${ }^{29}$ De potentia, q. 5 a. 1 arg. 13 "Praeterea, appetitus naturalis non potest esse cassus et vanus. Sed quaelibet res naturaliter conservationem sui esse appetit. Potest ergo res per se ipsam conservari in esse; alias appetitus naturalis esset vanus."

${ }^{30}$ De potentia, q. 5 a. 1 ad 13 "Ad decimumtertium dicendum, quod licet quaelibet res naturaliter appetat sui conservationem, non tamen quod a se conservetur, sed a sua causa."
} 
[conservationis appetitum] and a great hate of their own destruction [propriae destructionis odium] but also the faculty to recognize what is alike and similar and what is contrary and dissimilar [cognata similiaque et contraria dissimiliaque dignoscendi vim]" (I, 34, Latin quoted above). In other words, the doctrine of universal sensibility, in addition to identifying the teleological tendency of things within nature and not without it (as Giglioni stressed), also provides a fundament to explain the self-preserving action of things outside a theological framework, or, to use Telesio's expression, according to the principles of nature alone. In this context, the reference to God (the only one in the whole second book of De rerum natura!) is just a reminder of the role of the author of nature, and it seems to be merely a justification expost of the order and harmony of nature. Although active natures fight for the affirmation of their being and reciprocally seek to destroy each other, there seems to be a sort of measure in nature, from which beautiful things stem in great number according to a certain order. Telesio explains that this is due to "God the perfect and greatest, not the oblique motion of the Sun; this motion itself is indeed to be understood as a work of God and certainly as produced with admirable wisdom." ${ }^{31}$ Here, though, God is just the author of the world: he does not act as the final end of a thing's action, as in Aquinas. Again, the teleological tendencies of active principles, as well as nature in general, are to be found entirely within nature and not without.

\section{Self-preservation vs natural and violent motion}

How does this principle of self-preservation effectively come into play to explain natural phenomena? The most interesting application of the principle (and probably also the true motivation underlying Telesio's theory) is related to the explanation of the nature of motion, in particular as an objection to Aristotle's theory of natural motion. As known, the vulgate of Aristotle's physics proposed by the Scholastics divided motion into natural, i.e. motion caused by the form of the object and aimed rectilinearly at the centre of the corresponding sphere, and violent, i.e. motion caused by an external force and directed not in the direction otherwise followed by the thing in question. In this context, what we now call "acceleration of gravity" was seen as proportional to the weight of the object in question (in turn determined by its form) and

\footnotetext{
31 "Neque igitur sese mutuo perdant aut imminuant omnino quid, et longe plurima constituant longeque pulcherrima, et eadem semper ratione omnia. Hiuiusmodi Deus ipse Optimus Maximus, non obliqua Solis latio videatur, quae eiusdem Dei videri debet opus, et admirabili quidem constituta sapientia" (II, 37, 344).
} 
the density of the medium across which the object travels. ${ }^{32}$ The notion of natural motion, in particular, is at the centre of Telesio's criticism. Things, according to Telesio, cannot move and then rest. If movement pertains to a certain thing, it would continue indefinitely, and vice versa if a thing is at rest there is nothing in the thing itself that would make it move in a second moment. As the incipit of I, 43 recites,

The Earth is absolutely contrary to heaven and no motion corresponds to it, and the arguments of Aristotle according to which he attributes to it and to all other bodies a natural motion are absurd $[\ldots]^{33}$

\section{As Telesio continues,}

One shall not think that things that appear by their own nature to lie down and to be immobile, though they have been seen to reach spontaneously that place, are carried there by their own natural motion; for immobility and motion cannot be of the same nature; instead, it is necessary that things that are by nature immobile are entirely devoid of any motion, and that, in contrast, things that move by nature are always in motion and never stop moving $[\ldots]^{34}$

This leads to a radical rethinking of the Aristotelian doctrine of motion, which is harshly criticized. If a body falls to the Earth when dropped, this cannot be due to the fact that the body changes its state and becomes mobile after being motionless. On the contrary, it is precisely the absence of motion, together with its desire to preserve its being, that makes the body fall towards the centre of the Earth. In Telesio's account (and this is the first objection he raises against Aristotle), violent and natural motion do not seem to bear any crucial difference, whereas motion (or at least, a particula kind of motion) and rest do. Things in motion are not to stop. As he writes,

All motions [...] appear to differ one from another negligibly, in contrast to motion and rest, which, as also Aristotle states, derives from a nature that is opposite to that of motion and indeed is really contrary and opposed to motion; indeed, rest is opposed to labour [labori] not to motion thanks to which mobile things rest and take much pleasure and gain strength. ${ }^{35}$

\footnotetext{
${ }^{32}$ Aristotle, Physics (Stilwell: Digireads Publishing, 2006), Book IV.

${ }^{33}$ I, 43, 134: "Terram Coelo omnino contrariam esse, et nullum illi motum convenire, et absurdas esse Aristotelis rationes, quae motum illi naturalem et reliquis corporibus omnibus attribuunt, et cur deorsum sponte feratur."

34 "At eque quae in proprio loco natura quiescere et immobilia esse videntur, sponte etiam suam ad illum deferri visa, proprio et naturali motu deferri videri debent; neque enim et immobilitas et motus naturae uni convenire, sed quae natura immobilia sunt motus omnis penitus expertia sint necesse est, quae contra natura moventur perpetuo moveantur oportet, et moveri nunquam cessant" (I, 44, 137-139).

35 I, 43, 138: “...motus omnes, differre etiam inter se visos quid quam motum atque immobilitatem, quae vel Aristotelis testimonio ab opposita motui manat natura, et quae vere motui contraria est oppositaque; nam quies
} 
The notion of labour here is particularly relevant to explain the motion of cold things, which by nature would otherwise not move at all. Heavy things (things predominantly characterized by the principle of Earth) do not move downward because that is their natural motion, but because they seek their own preservation. In seeking their preservation, they force their natural disposition to rest (if they are cold) or to move with uniform motion (if they are hot), moving with increasing speed towards the Earth or moving non-uniformly. As he writes,

\begin{abstract}
The parts of the Earth, separated from their place and their totality, fall spontaneously and the more rapidly the bigger they are and the closer they are to their place, not because that motion is natural to the Earth itself or to its parts but because the desire, the care and love of all beings for their preservation and for similar beings, and the hate of their destruction and of contrary beings, and the sense of both things, are such that they seem to force their nature, and the immobile beings move and the mobile beings move with an unusual, albeit natural, motion. $^{36}$
\end{abstract}

The change in motion of warm, moving things is provoked by the interaction of external forces that threaten the preservation of their nature. Similarly, the downward motion of cold, earthly things is not a "natural" form of motion; rather they are forcing their own nature (arguably through what Telesio has just defined as "labour") until they can be one with the principle that ensures their self-preservation and increases their being. As Telesio writes,

...one shall not think that the parts of the Earth, while they fall towards their own place [proprium locum] and their own totality [universalitatem], move with natural motion, for once they have reached their totality they always become, like it, immobile; instead, one must think that they force their own nature and perform an action that is alien to their nature [ipsae naturae inferre vim et alienam tantisper operari operationem] until they reach their place and their totality. ${ }^{37}$

This leads to a second, and more interesting, criticism of the dichotomy between violent and natural motion. What Aristotle describes as the natural, downward motion of heavy things

labori opponitur, non motui in quo vel summe quiescunt summeque oblectantur et robur etiam sumut mobilia quae sunt entia."

${ }^{36}$ I, 43, 138: "Terra itaque partes, a proprio loco et a propria abstractae universitate, sponte delabuntur sua eoque velocius quo maiores et quo proprio loco propinquiores factae sint, non quod naturalis is vel Terrae ipsius vel eius partium motus sit, sed quod, ut expositum est, is entium omnium propriae conservationis et cognatorum appetitus studiumque est atque amor, propriaeque destructionis et contrariorum odium atque aversatio et utriusque sensus, ut propriae etiam naturae vim inferre videantur, et immobilia moveantur, et mobilia, si quidem naturali, insueto certe motu."

${ }^{37}$ I, 43, 138-140: "Quaere nec Terrae partes ad proprium locum et ad propriam descententes universitatem naturali motu moveri videri debent, quae ad ipsam delatae perpetuo veluti et ipsa immobiles fiunt, sed et ipsae naturae inferre vim et alienam tantisper operari operationem, quo ad proprium locum et ad propriam ferantur universitatem." 
cannot, Telesio claims, be so for it gradually increases, as Aristotle claims when he observes the fall of a stone towards the centre of its sphere. In contrast, the motion of things that move by nature is uniform. Analogously, violent motion cannot be characterized by a progressive decrease of its intensity. Instead, "natural motion" is constant by nature, since "the bodies that move by nature, since motion is the operation by which they preserve themselves to the highest degree, must always move with the same speed." 38 Here, we probably find an echo of the widespread Aristotelian and Ptolemaic idea according to which the motion of heavenly objects is characterized by constant speed. In this way, changes in motion are brought about by the presence of an external force (which Telesio identifies as a contrary nature) that threatens the preservation of the thing itself, or, conversely, by the thing's drive to self-preservation:

...the bodies that increase continuously [their speed] move not by nature but either because they are pushed by some evil, and the more they hate it the more they increase their motion, or because they are attracted by some good, and the more they are enticed by its sweetness the more desirously they pursue it. ${ }^{39}$

On this basis, Telesio begins a very detailed confutation of the Aristotelian explanation of the increase of speed of a falling stone, which his doctrine of self-preservation is meant to replace. This confutation reveals, I believe, the motivations of Telesio's theories of sentience and selfpreservation: his intention to provide an alternative to Aristotle's theory of motion. However, this motion cannot be deemed "natural", as natural motion, in Telesio's account, is characterized by constant speed and not by uniform acceleration. This overturns Aristotle's account of the difference between violent motion (characterized by progressive deceleration) and natural motion (characterized by constant acceleration). ${ }^{40}$

The increase of the speed of a falling object is at the centre of Telesio's polemic. According to Aristotle, Telesio explains, the stone, while approaching the ground, progressively re-acquires its nature of heaviness, which it partially lost because of its distance from its natural place and the

\footnotetext{
38 "At neque qui motus assidue magis concitatur naturalis is propriusque, sed praeter naturam omnino videri debet, non siquidem in eo a naturali violentus differre, quod hic assidue magis languescat, ille vero assidue veluti robur sumat et magis concitetur, sed quod perpetuo idem est nihilque vel remittitur vel concitatur unquam. Quae scilicet natura moventur, quoniammotus propria ipsorum operatio est et qua summe in propria servantur natura, perpetuo eodem ferantur oportet" (I, 45, 142).

39 "Quae itaque assidue illum concitant, non natura moveri videri debent, sed vel a malo aliquo impulsa quod assiudue magis abhorrescentia motum assidue concitant magis, vel a bono quopiam tracta cuius dulcedine magis assidue illecta maiore id sectentur studio..." (145).

40 "Propterea, quidam inquiunt, qui e sublimi dedicit lapis extremum et Terrae contiguum spatium velocius conficit, quod simili congataeque Terrae proximior factus, propriae naturae et propriae etiam gravitati quibus ab alieno loco et a contrariis veluti extus fuerat restituitur. Absurda sane ratio, et quae modis multis refelli possit” (145).
} 
action of the contraries. But how can the air, which is very weak, deprive the stone of its nature, since once dropped the stone does not even stop for a second? And how can the Earth immediately re-introduce the nature of heaviness to the stone? What is more, in this way a stone that is lifted only a little should move more quickly than one that is lifted higher in the air, since its distance from the Earth is smaller; yet experience shows us the contrary. ${ }^{41}$ In the second place, Telesio refutes the explanation based on the quantity of the medium. Accordingly, the stone would cut through the air below more easily the more it nears its natural place due to the decreasing quantity of air beneath it, and thus its motion would result in constant acceleration. Telesio deemed this explanation inconsistent. First, Telesio claims, the medium (air) is always the same substance. Second, the more the stone approaches its natural place, the more the medium must become dense due to the pressure that the falling object exerts. Third, the fact that the stone falls with less speed if dropped from a lower place represents a glaring confutation of this thesis. ${ }^{42}$ Lastly, Telesio confutes the antiperistatic explanation. According to this theory, the motion of objects (both natural and violent) is caused by the displacement of air that the moving object provokes, since a vacuum cannot exist in nature and the air displaced by the moving object would fill the space left by the object, in turn propelling it. When applied to the fall of the object, the tendency it has to move downward combined with increased pressure and push of the air above it would explain the acceleration of the falling stone, which therefore would be proportional to the increase of the mass of air above it. Once again, Telesio harshly criticizes this explanation. First, as in the case of violent motion, things do not increase their speed by virtue of

\footnotetext{
41 "Primum enim ne ipsi quidem qui ilam afferunt Peripatetici sibi ipsis (ut opinor) persuadeant, lapidem in sublime proiectum et nullo ibi temporis ammoratum momento a longe languidissimo aere propria natura propriaque exui gravitate, et leviorem omnino fieri, tum nullo itidem temporis momento a cognata Terra gravitatem illi indi; levitas enim gravitasque ne Aristoteli quidem agendi vi et se ipsas constituendi facultate praeditae videntur, sed illa quidem caloris, haec vero frigoris opus esse. Quoniam igitur paulo superior aer, non modo nihil inferiore calidior videri potest, sed vere frigidior existit, ut ad quem reflexa lux et languida et minus unita ascendit, nequaquam in eo levior fieri lapis videri potest. At ut calidior sit superior aer et levitas agendi vi praedita, non certe adeo nullo temporis momento lapidem tenuitate ulla aut ulla donent levitate, nec levior factus nullo itidem temporis momento gravior a cognata Terra fiat. Quin, si ea etiam omnia fiant, non vera sit ratio tamen, non scilicet Terrae proximior factus lapis propterea motum concitat, quod quae procul a Terra acto descendendi vires imminutae fuerant a propinqua Terra in integrum restituuntur; id enim si sit, ubi exiguum quid atollitur lapis nihil itaque levior fit spatium quo a Terra abest nihilo pigrius, forte etiam et velocius conficiat quam si e sublimiore decidat; secus omnino atque evenire videtur, quo enim a Terra minore sublatus est spatio, eo languidiore id delabitur motu, et eo idem vehementiore quo ex editiore descendat loco, ut manifeste descendendi vires non a Terra vicinitate, nec a re omnino alia ulla, at a descensus diurnitate augeri videantur" (147).

42 147.: “...quoniam enim lapidis magni praesertim delapsus aeris concessionem, et quasi fugam, praevenit atque antevertit, in angustius agatur suppositus aer atque in se ipsum conspissetur oportet, qui itaque dividi magis repugnet motum omnino descendentis lapidis impediat quid retardetque. At ex editiore is delabens extremum et Terrae contiguum spatium celeritate longe maxima, ex humili vero languidissimo illud idem conficere videtur motu."
} 
the action of the air but because of the force exerted on them. ${ }^{43}$ The air still moves to fill any empty space left by the moving object but its impetus cannot be strong enough to cause the propulsion of the object itself. Moreover, how can it be explained that once the object leaves the hand it starts moving spontaneously, without any empty space having yet been created ${ }^{44}$ In addition, the increase of the quantity of air above the falling object cannot explain the increase in downward movement of the stone, since only the air close to the object would be set in motion and not the rest of the air above it, which would tend to stay still. ${ }^{45}$ Furthermore, this would have paradoxical consequences in the case of violent motion. Even assuming that air, which is a thin and weak substance, possesses the force to move even a small object, and assuming that this force would increase proportionally to the quantity of the medium (i.e. the higher the object is positioned), a stone thrust upward with violent motion would continue to move indefinitely, as the push imparted by the increasing quantity of air beneath would increase proportionally. ${ }^{46}$

On this basis, Telesio concludes that the Peripatetics could not find any convincing explanation for the non-uniform speed of falling objects. The explanation of the acceleration of the falling stone can thus only be based on the notion of sentience and on that of selfpreservation: the stone hates contact with things that are contrary to its nature and increases its speed to enjoy as soon as it can its immobility among alike bodies. ${ }^{47}$ As Telesio writes,

The cause appears evident on the basis of what I have explained: that is, that the Earth, removed from its place and its totality, being immobile by nature, and hating very much this alien place and the contact with alien things, forces its nature and falls towards its own place and towards akin bodies; and this with increasing speed because, hating and being irritated by those [alien] things as much as by motion, it increases more and more the motion itself to enjoy as soon as possible its immobility among akin bodies. ${ }^{48}$

43 148: “...quae vi proiiciuntur, nequaquam ab aere ea impellente, ut Aristoteli placet, sed ab impressa vi deferri videntur."

44 148: "... satis enim sit aeri ne spatium ullum vacuum fiat providere, et nullo temporis momento eo accurrere unde necessit, quid, at non eo tamen impetu feratur oportet, ut non repleat modo relictum spatium, sed quod inde abiit impellat etiam stimuletque, siquidem propria natura in proprio loco immobilis Aristoteli aer, nequaquam prompte ac libens moveatur; at id modo quod moveri necesse est. Parum itaque a manu dimotus lapis, vel statim potius ac manu emissus est, coincidat; neque enim inter manum lapidemque spatium ullum inane factum est ad quod replendendum aeri sit convolandum."

45 "Tum si hac etiam ratione proiectorum motus fiat, non propterea aer universus ad Terram usque lapidem consectetur, sed proxima tantum assidue pars, quiescant reliquae et propria omnes gaudeant immobilitatem" (Ibid.).

46 “...perpetuo itaque moveantur quae vi moventur omnia, si siquidem modica aeris pars satis Aristoteli est sursum lapidem atollere, multo ubi longe facta est maiori idem possit. At non si ab impressa vi et ab indito ferantur motu, sed eo assidue languidius moveantur, quo a propellente removeantur magis, quo nimirum vis motusque inditus magis debilitetur magisque languescat" (I, 47, 150).

${ }^{47} \mathrm{I}, 47,150$.

48 "A proprio videlicet Terrae loco atque a propria abstracta universitate, propria quidem natura immobilis, at summe alienum locum atque alienorum exosa contactum, naturae vim infert et ad proprium locum atque ad cognata 


\section{Conclusion}

Telesio's argument relies on a strict analogy between human psychology and the natural world. The reason why earthly falling objects increase their motion is explained elsewhere through a comparison with the sense of anxiety (and at the same time of urgency) to reach pleasure or rest that we experience when we are doing something unpleasant:

...the more we deal with things that provoke annoyance to us, but that nevertheless we have to deal with, and that once they are finished they give us pleasure and rest, the more we increase our motion [or activity] despite hating and being bothered by the effort, since we increasingly desire the pleasure and rest that we are about to achieve. $^{49}$

During the seventeenth century, this "anthropomorphization" of nature (or naturalization of human psychology) would no longer be taken as a valid means to explain natural phenomena. For instance, in Principia Philosophiae, Descartes used the famous example of a stone revolving in a sling in order to explain his proto-inertial understanding of rectilinear motion. As Descartes claims, if released by the sling the stone would move rectilinearly. Circular motion is therefore constrained rectilinear motion. In this respect, Descartes claims that the stone "strives" to move away from its centre of revolution. But then he clarifies that his use of the expression "striving" does not entail any animistic hint:

...when I say that the globules of the second element 'strive' to move away from the centres ('recedere conantur $a b$ istis centris') around which they revolve, it should not be thought that I am implying that they have some thought from which this striving proceeds. I mean merely that they are positioned and pushed into motion in such a way that they will in fact travel in that direction, unless they are prevented by some other causes (II, 56.) ${ }^{50}$

The main aim of this passage was likely that of avoiding any possible charge of endorsing the animistic interpretation of natural phenomena that had characterized some of the most important natural philosophies of the Italian Renaissance (such as Telesio's) or in general the widespread

delabitur corpora, assideque id velocius quod et aliena illa et ipsum itidem exosa peraesaque motum assidue illum magis concitat, ut quam celerrime inter cognata propria gaudeat immobilitate" (I, 47, 150).

49 “...id quod nobis usu evenire interdum videntur; nam quae dum tractanctur molestiam inferunt, et peragenda omnino sunt, et quibus peractis voluptas proposita est et quies, quo magis ea tractamus eo motum magis concitamus, et opus exosi pertaesique et appropinquantis voluptatis quietisque magis appetentes" (I, 45, 144).

${ }^{50}$ René Descartes, "The Principles of Philosophy," in The Philosophical Writings of Descartes Vol. 1, ed. John Cottingham, Robert Stoothoff and Dugald Murdoch (Cambridge: Cambridge University Press, 1985), 259. 
use of psychological jargon in the physical discourse that characterized Scholastic physics. However, while here we find ourselves miles away from Telesio's explanation of motion, it is hard not to see some interesting similarities between Telesio's understanding of motion in terms of self-preservation and cognate seventeenth-century theories. Indeed, the example of the falling stone shows that Telesio's notion of self-preservation is complementary to that of universal sensibility, and it is very likely motivated by the search for an explanation of the origin of motion alternative to that offered by Aristotelian physics. Moreover, its autotelic, non-finalistic and antiprovidential character represents a trait of great discontinuity with respect to contemporary Scholastic physics. Providing a dichotomy between motion and rest, and understanding violent motion as a change of state due to the presence of an external force, it represents one of the first attempts to overcome the traditional Aristotelian picture of motion. In particular, when it comes to gravitation, his intuition that the downward motion of natural objects is not natural, but rather depends on the striving ("labor") of heavy objects to reconnect to their substance, strikes the reades as a clear detachment from Aristotelian-Scholastic physics.

While the notion of universal sensibility underlying this doctrine would generally be discarded by seventeenth-century mechanist philosophers, the idea that the behaviour of physical objects can be explained in terms of a tendency to the preservation of states would characterize seventeenth-century proto-inertial natural philosophies. Two remarkable examples of this tendency can be found in Descartes and Spinoza. Descartes' first law of nature in Principles of Philosophy would be explained in terms of a tendency to the preservation of states ("everything tends, so far as it can, to persist in the same state" II, 37), ${ }^{51}$ in turn rooted in the ordinary concourse of God. Spinoza would go as far as considering this striving towards self-preservation as the essential characteristic of all modes. ${ }^{52}$ As I have shown, the explanation of the tendency of motion of bodies in terms of seeking self-preservation was not a unique trait of Telesio's natural philosophy but rather part of a widespread tradition. However, certain traits of Telesio's theory of self-preservation, such as the fact that the process lacks any kind of terminus ad quem and hetero-teleological determination, would become a fundamental trait of seventeenth-century mechanism. While it is hard to assess Telesio's influence on these (and other) authors, it seems

\footnotetext{
${ }^{51}$ Descartes, "The Principles of Philosophy," 259.

${ }^{52}$ See for instance Ethics III, 6: "Everything, every thing, considered in itself, strives to persevere in its own being", in Baruch Spinoza, The Collected Works of Spinoza, ed. Edwin Curley (Princeton: Princeton University Press, 1985), 498.
} 
to me safe to speculate that his theory of motion helped to create the intellectual atmosphere from which early modern mechanism stemmed.

\section{Primary Sources}

Alarcón, Enrique. “Corpus Thomisticum.” www.corpusthomisticum.org, 2000.

Alighieri, Dante. Monarchy. Translated by Donald Nicholl. London: Weidenfeld \& Nicolson, 1954.

Aquinas, Thomas. On the Power of God. Translated by English Dominican Fathers. London: Burns Oates \& Washbourne, 1933.

-. De veritate. Electronic edition, http://www.corpusthomisticum.org.

-. Summa Theologiae. Electronic edition, http://www.corpusthomisticum.org.

Aristotle. Physics. Stilwell: Digireads Publishing, 2006.

Augustine. The City of God Against Pagans. Translated by George McCracken. Cambridge, MA: Harvard University Press, 1968.

Bonamici, Francesco. De Motu. Florence: Apud Sermartellium, 1591.

Cicero, Marcus Tullius. De Natura Deorum. Academica. Translated by Harry Rackham. Cambridge, MA: Harvard University Press, 1967.

Descartes, René. “The Principles of Philosophy." In The Philosophical Writings of Descartes Vol. 1, edited by John Cottingham, Robert Stoothoff and Dugald Murdoch. Cambridge: Cambridge University Press, 1985.

Goclenius, Rudolph. Lexicon Philosophicum. Frankfurt: Becker, 1613.

Laërtius, Diogenes. Life of Eminent Philosophers. Translated by Robert Drew Hicks. LondonNew York: Loeb Classical Library, 1925.

Spinoza, Baruch. The Collected Works of Spinoza. Edited by Edwin Curley. Princeton: Princeton University Press, 1985.

Telesio, Bernardino. La natura secondo i suoi principi. Translated by Roberto Bondì. Milan: Bompiani, 2009.

Secondary Sources 
Badaloni, Nicola. Tommaso Campanella. Milan: Feltrinelli, 1965.

Bondi, Roberto. Introduzione a Telesio. Rome: Laterza, 1997.

Cassirer, Ernst. Das Erkenntnisproblem in der Philosophie und Wissenschaft der neueren Zeit. Berlin: Verlag Bruno Cassirer, 1922.

Fiorentino, Francesco. Bernardino Telesio, Ossia Studi Su L’idea Della Natura Nel Risorgimento Italiano. Vol. 2. Florence: Le Monnier, 1974.

Gentile, Giovanni. "Bernardino Telesio." In Opere complete di Giovanni Gentile: I problemi della Scolastica e il pensiero Italiano. 133-206. Florence: Sansoni, 1963.

Giglioni, Guido. "The First of the Moderns or the Last of the Ancients? Bernardino Telesio on Nature and Sentience." Bruniana \& Campanelliana 1 (2010): 68-89.

Mulsow, Martin. Frühneuzeitliche Selbsterhaltung: Telesio und die Naturphilosophie der Renaissance. Tübingen: Niemeyer, 1998.

Schuhmann, Karl. "Hobbes and Renaissance Philosophy." In Hobbes Oggi, edited by Andrea Napoli. Milan: Angeli, 1990.

Wolfson, Harry Austryn. The Philosophy of Spinoza. Cambridge, MA: Harvard University Press, 1934. 